\title{
THE MALAYSIAN SECONDARY SCHOOL EFL SPEAKING CURRICULUM: A THEORETICAL FOUNDATION ALIGNMENT ANALYSIS
}

\section{Hazleena Baharun ${ }^{1 *}$, Harison Mohd Sidek ${ }^{2,}$, Noor Saazai Mat Saad ${ }^{3}$, Mohd Muzhafar Mohd Idrus $^{4}$, Haliza Harun ${ }^{5}$, Ramiaida Darmi ${ }^{6}$, Norhana Abdullah ${ }^{7}$ and Zarina Ashikin Zakaria $^{8}$}

${ }^{1}$ Dr., Islamic Science University of Malaysia, MALAYSIA, hazleena@usim.edu.my

${ }^{2}$ Assoc. Prof. Dr., Islamic Science University of Malaysia, MALAYSIA, harison@usim.edu.my

${ }^{3}$ Dr., Islamic Science University of Malaysia, MALAYSIA, noorsaazai@usim.edu.my

${ }^{4}$ Dr., Islamic Science University of Malaysia, MALAYSIA, muzhafaridrus@usim.edu.my

${ }^{5}$ Dr., Islamic Science University of Malaysia, MALAYSIA, haliza@usim.edu.my

${ }^{6} \mathrm{Dr}$., Islamic Science University of Malaysia, MALAYSIA, ramiaida@usim.edu.my

${ }^{7}$ Ms., Islamic Science University of Malaysia, MALAYSIA, hana66@usim.edu.my

${ }^{8}$ Ms., Islamic Science University of Malaysia, MALAYSIA, zarina@usim.edu.my

${ }^{*}$ Corresponding author

\begin{abstract}
Goal-achieving curricular are often coherent at their fundamental level. In order for a curriculum to achieve its goals, it is imperative that the curriculum is coherent at all levels. The contents presented in a curriculum must align with its theoretical underpinning. The present Malaysian English language curriculum is developed and designed based on the Communicative Language Teaching (CLT). Thus, the purpose of the current study was to examine if the theoretical grounding of the Malaysian form five English language curriculum, in particular the speaking curriculum, is in alignment with its communicative label. In line with its label, the speaking curriculum embedded in the Malaysian form five English language curriculum should be developed and designed based on the CLT. It should reflect the CLT approach. The data for this study were collected from the Form Five English Language Curriculum Specifications document and the Form Five English Language textbook. In analyzing the alignment of the Malaysian form five English language speaking curriculum with the communicative approach, the data were categorized under major second language acquisition (SLA) theories and second language (L2) speaking theories. The findings show that the sociocognitive and socio-cultural theories are highly reflected in the Malaysian form five English Language speaking curriculum, the two theories which are closely related to the communicative approach. This shows that the Malaysian form five English language speaking curriculum is primarily in alignment with its communicative label. The findings are discussed in relation to their implications on English as a foreign language (EFL) speaking instruction.
\end{abstract}

Keywords: Communicative Language Teaching, L2 speaking theories, English language speaking curriculum 


\section{INTRODUCTION}

Every curriculum is based on a particular theoretical orientation about language teaching and language learning (Basturkmen, 1999; Richards \& Rogers, 2001; Sidek; 2010a; 2010c). In order for an educational curriculum to be effective and to achieve its goals, it has to be coherent at all levels including at its theoretical level. A coherent curriculum should be reflective of the intended approach. Many studies on curriculum found that an incoherent curriculum often defeats the curriculum goals. Such a consequence may be due to the misalignment between the classroom implementation, textbook development and the intended approach of the curriculum (e.g. Rahman, 2014; Sidek et al., 2014).

Since secondary schools are the feeders of higher education institutions, the curriculum at the school level should be developed carefully in order to ensure that the curriculum meet its objective to produce competent students that are fully functional at the university level not only in academic areas, but also in the English language. Since curriculum reflects the intended instruction, the alignment of theory and practice is also of concern (e.g., Sidek, 2010c). One of the areas in the English language that is of significance is the speaking skill. Students' inability in the English language speaking skill may have adverse effect on their academic performance (Sabri, U. \& Qin, T. Y., 2014). The difficulty in communicating in English among university students is a critical issue within the Malaysian context (Sabri, U. \& Qin, T. Y., 2014). For example, the Malaysian Examinations Council (MPM) reported that in March 2015, a total of 48,708 candidates took the Malaysian University English Test (MUET). From these, only $0.3 \%$ obtained Band 6 (highly proficient user), 4.7\% Band 5 (proficient user) and $26.7 \%$ obtained Band 4 for speaking (satisfactory user). A majority of the candidates (68.29\%) were Bands $1-3$ (very limited to modest user) achievers. Examiners reported that these candidates did not perform well during their speaking examination. They generally lacked planning and organization, were hesitant in speech with frequent pauses, lacked vocabulary to express opinions, failed to elaborate on their ideas; the elaboration, if any, was usually limited, too simple, and disconnected which appeared superficial and disorganized, and made many grammatical errors during their speaking examination (MPM, 2015). Such poor performance has impacted university students in meeting the English language proficiency requirement for university enrollment and graduation. It is even more challenging for the students when some local institutions like USIM and UiTM use English as their medium of instruction. This means that EFL speaking proficiency is required for academic-based communication in the classroom such as for classroom presentations. Therefore, if students are not able to speak English well, such deficit will be at the expense of their academic performance, particularly in relation to all assessments that involve oral presentation in English. Furthermore, for institutions such as USIM and IIUM in particular, there are many international lecturers and students. Hence, EFL speaking proficiency becomes a necessity, especially for academic-related interaction.

The root of these issues can be traced back to the secondary school level, at which the Malaysian students are trained with the English language proficiency, which includes English language speaking. English language speaking skill deficit, particularly among students at the university level is a phenomenon that can be investigated by examining the English language speaking curriculum embedded in the Malaysian Secondary School English Language Curriculum. Therefore, a study on The English language speaking curriculum is imperative to ensure that the curriculum is coherent in order to alleviate the English language speaking deficit to a level that it is no longer significant. Within the context of the current study, the preliminary investigation of the curriculum's coherence was conducted at the approach or theoretical level in terms of its alignment with its current label.

\section{THE MALAYSIAN FORM FIVE SECONDARY SCHOOL ENGLISH LANGUAGE CURRICULUM}

The present Malaysian Form Five Secondary School English language curriculum revised in 2003 adopted the general proficiency approach. It is based on learning outcomes geared towards equipping students to communicate effectively, function appropriately in everyday life, and access information as well as able to understand and respond to literary works. English grammar, phonology, vocabulary, ICT skills, thinking skills as well as values and citizenship education were also included in the curriculum. In other words, English language is taught to learners in order to enable them to "use the language to further their studies and for work purposes" (Form Five English Language Curriculum Specifications, Malaysian Ministry of Education, 2003, p. 1).

Based on the curriculum document, the four language skills i.e. listening, speaking, reading and writing are integrated into the areas of language use. In other words, when learners use the language, they talk and listen to each other. In addition, they also write to each other letters and messages. Of the five broad areas introduced are people, environment, social issues, health, and science and technology. These five areas are 
translated into topics using tasks and activities in order to enable learners to read, write and talk about them. In task-based instruction, learners use language to transact or perform tasks rather than learn individual language items (Foster, 1999, Nassaji \& Tian, 2010). The tasks in focus are group communication tasks that require learners to work together in small groups or pairs. When they work in small groups, learners have more "opportunities to participate, observe, reflect on and practice socially shared ways of knowing and thinking" (Kumpulainen \& Wray, 2002, p. 3). It is argued that these communication tasks provide opportunities for learners to practise language and to negotiate meaning (Long \& Porter, 1985). Thus, it could be concluded that the Malaysian Form Five Secondary School English language curriculum was developed based on the principles of Communicative Language Teaching (CLT) in the form of Communicative Task-Based Language Teaching.

The objectives of the Form Five English language curriculum include the ability to talk about experiences and exchange ideas with friends and relatives, ask questions and respond to questions with relevant answers, make plans and arrangements with friends to do something or go somewhere, obtain information from various sources and present these ideas to friends orally and in writing, read widely and enjoy poems and short stories, and show an awareness and appreciation of moral values and love towards the nation. The curriculum however, does not have an exclusive speaking curriculum and objectives. Nonetheless, based on the general objectives outlined in the curriculum document, it is observed that the speaking objectives are integrated and included in the general objectives.

\section{THE COMMUNICATIVE LANGUAGE TEACHING (CLT) APPROACH}

What is communicative language teaching (CLT)? According to Brandl (2007), "communicative language teaching (CLT) is generally regarded as an approach to language teaching (Richards and Rodgers, 2001, p. 5)". It does not adhere to any particular theory or method. Even though CLT does not adhere to one particular theory or method, it is based on the theory that the main function of language use is communication as the primary goal of CLT is for learners to develop communicative competence (Hymes 1972).

\subsection{Second Language Acquisition (SLA) Theories}

The Vygotskian's Socio-Cultural Theory (SCT) stresses on the role of social interaction in language acquisition. It claims that interaction is an opportunity to learn. According to the SCT, human cognitive development is a socially situated activity mediated by language (Vygotsky, 1978). This means that knowledge is socially constructed by interaction and is then internalized. It is also through interaction that learners regulate or restructure their knowledge. Within the socio-cultural approach to L2, knowledge is constructed through social interaction between individuals and is then internalised (Vygotsky, 1978). This is because interaction allows mediation process to take place. Ashman and Gillies (2003) define mediation as the "need for someone other than the learner to translate knowledge about the society and culture so that it can be internalised" (p.199). The underlying assumption is that knowledge is created through interaction and not simply transferred. In other words, during social interaction, as learners negotiate, they have the opportunity to develop not only their language skills but also their cognitive and problem solving abilities (Swain \& Lapkin, 2002). Thus, in this case, CLT could be viewed as "in line with socio-cultural theory (SCT), which views language as a tool in a socially mediated process (Vygotsky, 1978) and as a central tool for the development of thought processes or the crucial means of mediation for one's cognition" (Sidek, 2012, p. 110).

Another SLA theory that is closely related to CLT is the socio-cognitive theory. Based on the socio-cognitive theory, interaction promotes language learning. One is through the context of social interaction and the other is through interaction with the environment. Thus, "an individual's environment and changes in that environment affect the individual's thought processes which in turns influences the development of his or her language acquisition" (Matsuoka \& Evans, 2004 cited in Sidek, 2010a, p. 24). The SCT and the sociocognitive theory overlaps in the way they view language i.e., as cognitive and social in nature. Unlike the SCT, the socio-cognitive theory "does not promote communicative competence as central to language activities" (Sidek, 2010a, p. 24). The socio-cognitive theory is rather limited to the interaction between the mind, the body and the language without taking into account the role of others or context. On the contrary, the SCT includes the elements within the realm of socio-cognitive theory with additional concern in the role of the context. Nonetheless, due to its emphasis on interaction, the CLT is very much in line with the sociocognitive theory views on SLA.

\subsection{Second language (L2) speaking theories}

The Output Hypothesis (Swain, 1985, 1995, 2005) claims that the act of producing language (speaking or 
writing) constitutes part of the process of second language learning. During interaction, learners receive feedback on the form and meaning of their messages, whether or not they are understood by others. If their messages could not be comprehended by others, they need to do something. This leads them to modify their speech in order to enhance the comprehensibility of their message. In this case, in order to make themselves understood better by others, the learners are pushed in their production. At the same time, they also push other speakers to do the same (i.e., modify their speech) so that comprehensibility is achieved. In sum, the whole idea of interaction, negotiation and output is very much emphasized.

The Interaction Hypothesis (Long, 1996) suggests a number of ways in which interaction can contribute to language acquisition. In general terms, it proposes that the more opportunities learners have to negotiate, both meaning and content, the more likely they would acquire the language. In other words, negotiation for meaning is an activity that occurs as a result of interaction "in which learners seek clarification, confirmation, and repetition of L2 utterances they do not understand" (Pica, 1994, p. 56). When learners fail to understand input or when they display a lack of control over a form, whether grammatical or lexical, they negotiate. What they do is that they ask questions, seek clarification and request for explanation; these moves inform other speakers that their utterance is somehow difficult to understand. The other speakers would make modifications so that input is comprehended or understood by the learners. Thus, specifically IH suggests " 1 ) that when interactional modifications lead to comprehensible input via decomposition and segmenting of input, acquisition is facilitated; 2) that when learners receive feedback, acquisition is facilitated, and 3) that when learners are pushed to reformulate their own utterances, acquisition is promoted" (Ellis, 2003, p. 80). This is because, as argued by Swain (1995), "learners need to be pushed to make use of their resources; they need to have their linguistic abilities stretched to their fullest; they need to reflect on their output and consider ways of modifying it to enhance comprehensibility, appropriateness, and accuracy" (p. 160). When learners are pushed in their production, they cannot avoid paying attention to language forms as they would do in comprehension. Learners would process language both semantically and syntactically. It is when learners are pushed to produce language that is accurate and precise that second language acquisition is promoted.

Within the realm of CLT approach to speaking, learners often play the role as a negotiator. They interact and negotiate meaning in small groups or as a whole class in order to complete tasks assigned to them. In this case, though not specifically labelled as $\mathrm{L} 2$ speaking theories, both $\mathrm{IH}$ and $\mathrm{OH}$ are very much in line with the CLT approach. Both $\mathrm{IH}$ and $\mathrm{OH}$ emphasize the importance of interaction, negotiation and output in order to promote speaking in SLA. Thus, speaking activities based on $\mathrm{IH}$ and $\mathrm{OH}$ may include activities among others that require learners to discuss in small groups, express opinions and contribute ideas on issues.

\section{THE STUDY}

In the Malaysian context, students at Malaysian schools receive 11 years of English as a foreign language (EFL) instruction. Nonetheless, it is a phenomenon that the Malaysian students are still not competent in the English language. Numerous studies on EFL (e.g., Sidek, 2010b-EFL reading attitudes; Sidek, 2012-EFL personality traits; Sidek \& Rahim, 2013; 2015-cross-linguistics; Abdullah \& Sidek, 2012—writing feedback; Saad et al., 2016a; 2016b-EFL learning experience; Baharun et al., 2016-Task-based learning; Sidek et. Al, 2016a-EFL reading fluency; Sidek et al., 2016b_abstract writing in EFL) have been conducted including EFL speaking. Studies on EFL speaking have also been widely conducted within the Malaysian setting to investigate different issues related to EFL speaking. They include among others research on language anxiety among English language learners and their speaking performance (Abdul Aziz, N. H., 2007; Chan, S.H., Abdullah, A.N. \& Yusuf, N., 2012), using tasks to foster learners' speaking abilities (Mohammadipour \& S. MD. Rashid, 2015), using films to teach speaking in the EFL classrooms (Shing, S. R. \& Yin, L. K., 2014) and turn-taking strategies among learners in class discussion (Rahmat, N. H., Rahman, S. A. B. S. A. \& Yunos, D. R. M., 2015). The abovementioned studies primarily focused on learners and their speaking performance. Not many have been done at the root of it, which is the curriculum itself.

It has been found that despite its importance being the foundation of the EFL instruction, studies on EFL speaking curriculum at the secondary school level are scarce/or if had been conducted, they are currently not available in the mainstream publications. Currently, studies on the Malaysian EFL curriculum had only been conducted on EFL secondary school reading curriculum (e.g. Sidek, H. M., 2012a, 2012b, 2013, 2014; Sidek, H. M. \& Abdullah, H., 2013; Sidek, H. M., Abdullah, H. \& Rahim, H.A., 2013). Hence, this study was a pioneering study of its nature as to the best of the researchers' knowledge; such study has never been conducted in Malaysia neither in other EFL settings. The aim was to investigate and examine the Malaysian EFL secondary school speaking curriculum and its communicative label. It further aimed to make suitable recommendation to the relevant authorities on how to refine the Malaysian EFL speaking secondary school curriculum at the level of Approach in order to enhance the effectiveness of the EFL speaking program. 


\section{METHODOLOGY}

\subsection{Research approach}

The method of analyzing the Malaysian EFL secondary speaking curriculum in this study is substantially influenced by the language teaching model of Richards and Rodgers (2001), a revision of Edward Anthony's (1963) model. This model presents a conceptual framework for language instruction proposing that at the fundamental level, language instruction can be analyzed in terms of Approach (foundational theory), Design (e.g., selected language skills, learning tasks, learner roles), and Procedure (e.g., classroom techniques, classroom observation, teacher interviews). However, as this study examined the curriculum coherence in terms of the alignment of theories and the overarching approaches to second language (L2) speaking instruction that are reflected in the Malaysian EFL secondary speaking curriculum and instruction, only the Approach component in Richards and Rodgers' (2001) language instruction conceptual frameworks was applicable to the study, although with modifications.

\subsection{Research questions}

The present Malaysian English language curriculum is developed and designed based on the CLT. Thus, the purpose of the current study was to examine if the theoretical groundings of the Malaysian form five English language curriculum, in particular the speaking curriculum, is in alignment with its communicative label. The study sought to answer the following research questions (RQs):

$\mathrm{RQ1}$ : What are the SLA theories reflected in the form five English language speaking curriculum?

RQ2: What are the L2 speaking theories reflected in the form five English language speaking curriculum?

\subsection{Data collection}

To address the research questions posed in this current study, we used document analysis as the research instrument to generate data. The sources of data were in the form of speaking-related statements extracted from two written documents. The documents were the:

i) Form Five English Language Curriculum Specifications (Malaysian Ministry of Education, 2003) - this document is used by teachers of English language as their teaching guidelines.

ii) Form Five English Language Textbook - this book is used by both English language teachers and form five students in the classroom during English language lessons.

\subsection{Data analysis}

Richards and Rodgers' (2001) model at the Approach level provides a tool for analyzing the Malaysian secondary EFL speaking instructional approach in terms of its grounded foundational theories of SLA and theories of L2 speaking. Hence, for the present study, only the 'Approach' aspect was relevant as the aim was to determine whether the theoretical groundings of the Malaysian form five English language curriculum, in particular the speaking curriculum, is in alignment with its communicative label. To answer the research questions, the current study extracted speaking-related statements from the Form Five English Language Curriculum Specifications (Malaysian Ministry of Education, 2003) and the Form Five English Language Textbook. The data from the two sources were analyzed using straightforward percentages and compared in order to determine the alignments. The analysis for each research question is explained individually.

$\mathrm{RQ1}$ : What are the SLA theories reflected in the form five English language speaking curriculum?

Based on the reviews of SLA theories, the speaking-related statements in the curriculum specifications and in the textbook were inferred as one of the three prominent SLA theories: structuralism, socio-cognitive theory and socio-cultural. The structuralism theory was inferred in statements such as saying words after the teacher and taking turns to say sentences with the correct intonation, word stress and sentence rhythm. The socio-cognitive theory was inferred in statements such as presenting speeches. The socio-cultural theory of SLA was inferred in statements such as interviewing people to get more information, engaging in small group discussions and responding to questions and comments. From the researchers' preliminary examination of the curriculum documents, these are the major SLA theories reflected in the documents. As such, these theories were selected as the coding for the current study at the level of approach.

$\mathrm{RQ2}$ : What are the L2 speaking theories reflected in the form five English language speaking curriculum?

Based on the reviews of L2 speaking theories, the speaking-related statements in the curriculum 
specifications and in the textbook were inferred as one of the three prominent L2 theories: behaviourist, cognitive and communicative-based interactive theory. The behaviourist theory was inferred in statements such as pronouncing the words correctly, reading the dialogue and practising the following ways of expressing opinions. The cognitive theory was inferred in statements such as giving speeches and reporting findings. The communicative-based interactive theory was inferred in statements such as discussing and exchanging ideas, expressing opinions and asking questions either in pairs or small groups.

\section{FINDINGS}

\subsection{SLA theories reflected in the form five English language speaking curriculum}

This section presents the findings for the first research question: What are the SLA theories reflected in the form five English language speaking curriculum?

In terms of the SLA theories, findings revealed that the SCT was prominent as reflected in the form five English language speaking curriculum in both the Form Five English Language Curriculum Specifications and in the Form Five English Language Textbook that were examined, findings revealed that the SCT was prominent. This could be observed in the speaking related statements identified in both documents. A total of $94.7 \%$ of the speaking-related statements identified in the curriculum specifications exhibited the SCT approach. The speaking-related statements identified in the English language textbook also exhibited similar findings. A total of $68.8 \%$ of the speaking-related statements identified in the textbook reflect the SCT approach that underpins CLT in which the curriculum was developed. While a majority of the speakingrelated statements in both documents $(94.7 \%$ and $68.8 \%)$ reflected the SCT approach to SLA, a total of $3.5 \%$ of the speaking-related statements from the curriculum specifications and $15.2 \%$ of the speakingrelated statements identified in the English language textbook reflects the socio-cognitive theory approach. Further, even though the form five Malaysian English language curriculum was developed based on CLT with SCT as its underpinning theory, it is found that there is a trace of structuralism as well in the speakingrelated statements both in the curriculum specifications (1.8\%) as well as in the English language textbook (16\%). These are shown in Table 1.

Table 1: Analysis of SLA theories in the English language speaking curriculum

\begin{tabular}{|c|c|c|c|}
\hline Documents/SLA Theories & $\begin{array}{c}\text { Socio-Cultural Theory } \\
(\%)\end{array}$ & $\begin{array}{c}\text { Socio-Cognitive Theory } \\
(\%)\end{array}$ & $\begin{array}{c}\text { Structuralism } \\
(\%)\end{array}$ \\
\hline $\begin{array}{c}\text { Form Five English } \\
\text { Language Curriculum } \\
\text { Specifications }\end{array}$ & 94.7 & 3.5 & 1.8 \\
\hline $\begin{array}{c}\text { Form Five English } \\
\text { Language Textbook }\end{array}$ & 68.8 & 15.2 & 16 \\
\hline
\end{tabular}

\subsection{L2 speaking theories reflected in the form five English language speaking curriculum}

This section presents the findings for the second research question: What are the L2 speaking theories reflected in the form five English language speaking curriculum?

The $\mathrm{IH}$ and $\mathrm{OH}$ are the most prominent $\mathrm{L} 2$ speaking theories reflected in both documents - the form five English speaking curriculum specifications document (94.7\%) and the textbook (68.8\%). Both hypotheses are in line with the SCT, which underpins the CLT approach to the curriculum. They place great emphasis on interaction, negotiation and output in speaking. These could be observed in the speaking tasks for instance, which require learners to take part in conversations and discussion, and exchange ideas, information and opinions on topics of interest.

The Whole Language instructional approach, a corresponding teaching approach for the cognitive theory, was developed based on the theory of language as communication or social activity. Even though the approach is dominant in the realm of L2 reading, as a teaching approach, speaking is also included. However, it is mainly as a non-communicative teaching approach for speaking. It primarily involved individual speaking tasks such as presenting speeches without any direct interaction with others in the context. This is reflected in both documents examined - the form five English speaking curriculum specifications document (3.5\%) and the textbook (15.2\%).

Despite the emphasis on communicative abilities, the curriculum specification and textbook used still place 
emphasis on accurate production of the target language form, albeit not the primary focus. The L2 speaking theory reflected in the speaking curriculum is related to the behaviourist theory. This could be observed in some of the speaking-related statements identified in the documents. The statements both in the curriculum specifications $(1.8 \%)$ and in the textbook $(16 \%)$ placed emphasis on accurate repetition of dialogues, oral drills and pattern practice. These are common oral activities that are in line with the behaviourist learning theory as it is believed that "in order to acquire a language one needs to acquire the forms of the language, which are best taught using reinforcement or repetitive practices" (Sidek, 2010a, p. 29). Findings are shown in Table 2.

Table 2: Analysis of L2 speaking theories in the English language speaking curriculum

\begin{tabular}{|c|c|c|c|}
\hline $\begin{array}{c}\text { Documents/L2 Speaking } \\
\text { Theories }\end{array}$ & $\begin{array}{c}\text { Interactive Theories } \\
(\mathrm{IH} \mathrm{\&} \mathrm{OH)} \mathrm{( \% )}\end{array}$ & $\begin{array}{c}\text { Cognitive Theory } \\
\text { (Whole-Language } \\
\text { Approach) }(\%)\end{array}$ & $\begin{array}{c}\text { Behaviourist } \\
\text { (Audio Lingual Method) } \\
(\%)\end{array}$ \\
\hline $\begin{array}{c}\text { Form Five English } \\
\text { Language Curriculum } \\
\text { Specifications }\end{array}$ & 94.7 & 3.5 & 1.8 \\
\hline $\begin{array}{c}\text { Form Five English } \\
\text { Language Textbook }\end{array}$ & 68.8 & 15.2 & 16 \\
\hline
\end{tabular}

\section{DISCUSSION}

Even though from the total percentage of the SLA and L2 speaking theories calculated from each document did not show a total of $100 \%$ in terms of its alignment with its communicative label, it can still be considered communicative in nature as each document recorded more than $50 \%$. In sum, the overall findings suggest that the SLA theories and L2 speaking theories identified in the Malaysian secondary English language curriculum reflect the SCT in which the CLT approach to language learning and teaching it underpins. The two main documents examined (the Form Five English Language Curriculum Specifications and the Form Five English Language Textbook) show that the theoretical grounding of the Malaysian form five English language curriculum, in particular the speaking curriculum, is in alignment with its communicative label.

In line with its communicative label, the speaking curriculum embedded in the Malaysian form five English language curriculum was developed and designed based on the CLT and reflects the CLT approach. This could be observed in the speaking-related statements as well as the speaking tasks identified in the curriculum specifications and the textbook used by the learners in the form of Communicative Task-Based Language Teaching. Hence, it can assumed or expected that learners who have gone through five years of secondary schooling should possess an acceptable communicative ability in order to "meet their future needs for English in everyday life, for knowledge acquisition, and for future workplace needs" (Form Five English Language Curriculum Specifications, Malaysian Ministry of Education, 2003, p. 1).

However, as mentioned earlier in the introduction section of this paper, learners still have problems in the realm of speaking as exhibited in results of national examinations such as MUET. This could affect their academic performance at tertiary level, a situation, which makes secondary school English language preparation more crucial among secondary school students. Many university courses especially at private universities require classroom presentations in English as part of their course requirements. In addition, many students who obtain scholarship to continue their tertiary studies in English speaking countries often face with difficulties in communication via the English language in their academic courses. Hence, the problem of low communicative abilities of the local learners needs to be addressed. Based on the findings, in which that the Malaysian form five English language speaking curriculum is primarily in alignment with its communicative label, so it could be concluded that the problem may not be due to the curriculum. Thus, further research needs to be conducted on the other aspects of language instructions which are the Design (e.g., selected language skills, learning tasks, learner roles), and Procedure (e.g., classroom techniques, classroom observation, teacher interviews) in order to identify the root of the problem plaguing the Malaysian learners particularly in the area of speaking.

\section{CONCLUSIONS}

The curriculum considered is in alignment with its communicative label; nevertheless the alignment needs to be revised. In terms of SLA and L2 speaking theories, members of curriculum development panel at the ministerial level for EFL need to have a clear understanding of the selected theories that underpin the curriculum. It is imperative that those who develop the secondary speaking curriculum have the right knowledge and understanding of the principles of CLT, the related SLA theories that underpin the approach 
and the L2 speaking theories as well as the related communicative instructional approaches. Additionally, learner role must meet the characteristics prescribed by the SCT. It is equally important that textbook writers are also equipped with similar knowledge and understanding as the curriculum developers. This will ensure that textbooks are written in alignment with the approach intended.

\section{ACKNOWKLEDGEMENT}

This research was financially supported by Islamic Science University of Malaysia (USIM) (Grant NO. PPP/USG-0215/FPBU/30/16015).

\section{REFERENCE LIST}

Abdul Aziz, N. H. (2007). ESL students' perspectives on language anxiety. Unpublished PhD. Thesis, Universiti Putra Malaysia: Serdang.

Abdullah. H \& Sidek, H.M. (2012). L2 writing feedback: Alignment of instructional planning and implementation. Journal of Language Studies, 15, 15-17.

A. Rahman, N. H. (2014). From curriculum reform to classroom practice: An evaluation of the English primary curriculum in Malaysia. Unpublished PhD Thesis, University of York.

Anthony, E. (1963). Approach, method, and technique. English Language Teaching, 17(2), 63-67.

Ashman, A., \& Gillies, R. (Eds.). (2003). Cooperative learning: The social and intellectual outcomes of learning in groups. Routledge.

Baharun, H., Sidek, H.M., M.M. Idrus, N.S.M. Saad, (2016). Task-Based Language Learning: Investigating the Dynamic of Learners' Oral Interaction. International E-journal of Advances in Social Sciences, 2(5), 570-580.

Basturkmen, H. L. (1999). A content analysis of ELT textbook blurbs: Reflections of theory in use. RELC, 30(18), 20-38.

Brandl, K. (2007). Principles of communicative language teaching and task-based instruction. Communicative language teaching in action: Putting principles to work, 1-38.

Chan, S.H., Abdullah, A.N. \& Yusuf, N. (2012). Investigating the construct of anxiety in relation to speaking skills among ESL tertiary learners. 3L: The Southeast Asian Journal of English Language Studies, 18(3), 155-166.

Ellis, R. (2003). Task-Based Language Learning and Teaching. Oxford: Oxford University Press.

Form Five English Language Curriculum Specifications. (2003). Ministry of Education, Malaysia (MOE). Retrieve from http://www.moe.gov.my.

Foster, P. (1999). Task-based learning and pedagogy. ELT Journal, 53(1), 69-70.

Hymes, D. (1972). On communicative competence. In J. B. Pride \& J. Holmes (eds.), Sociolinguistics (pp. 269-293). Harmondsworth: Penguin.

Kumpulainen, K. \& Wray, D. (2002). (Eds). Classroom interaction and social learning: from theory to practice. New York: Routledge Falmer.

Long, M. H. (1996). The role of the linguistic environment in second language acquisition. In W. Ritchie and T.K. Bhatia (Eds.), Handbook of research on language acquisition: Second language acquisition volume 2. New York: Academic Press.

Long, M. H. \& Porter, P. (1985). Group work, interlanguage talk and second language acquisition. TESOL Quarterly, 19(2), 207-228

Majlis Peperiksaan Malaysia (2015). http://portal.mpm.edu.my/en/statistik-perkhidmatan-online.

Matsuoka, R. \& Evans, D. R. (2004). Socio-cognitive approach in second language acquisition research. Journal of Nursing Studies, 3(1), 1-9.

Mohammadipour, M. \& MD. Rashid, S. (2015). The Impact of Task-Based Instruction Program on Fostering ESL Learners' Speaking Ability: A Cognitive Approach. Advances in Language and Literary Studies, 
6(2), 113-126.

Nassaji, H. \& Tian, J. (2010). Collaboative and individual output tasks and their effects on learning English phrasal verbs. Language Teaching Research, 14(4), 397-419.

Pica, T. (1994). Questions from the language classroom: research perspectives. TESOL Quarterly, 28, 4979.

Rahmat, N. H., Rahman, S. A. B. S. A. \& Yunos, D. R. M. (2015). Investigating turntaking strategies in class discussions among ESL adult learners. English Review: Journal of English Education, 3(2), 139-144.

Richards, J. C. \& Rodgers, T. (2001). Approaches and Methods in Language Teaching (2ed). New York: Cambridge University Press.

Saad, N.S.M., Yamat, Y., Sidek, H.M., Baharun, H. \& Idrus, M.M. (2016a), Acts of Agency in English Language Learning Experience. International E-journal of Advances in Social Sciences, 2(6), 733746.

Saad, N.S.M., Sidek, H.M., Baharun, H. \& Idrus, M.M. \& Yunus. M.Y. (2016b). A Conceptual Framework to Explore the English Language Learning Experiences of International Students in Malaysia. International E-journal of Advances in Social Sciences, 2(6), 453-464.

Sabri, U. \& Qin, T. Y. (2014). Communication apprehension among Nilai college students. Advances in Language and Literary Studies, 5(5), 46-49.

Shing, S. R. \& Yin, L. K. (2014). Using films to teach speaking in the ESL classroom: A case study. UNISEL Journal of Social Sciences and Humanities, 1(1), 50-56.

Sidek, H. M. (2010a). An analysis of the EFL secondary reading curriculum in Malaysia: approaches to reading and preparation for higher education. Doctor of Philosophy, University of Pittsburgh.

Sidek, H.M. (2010b). Reading Attitudes a Case Study in Malaysia. Annals of Language Teaching, (pp. 209215), Boca Raton, Florida: Universal-Publishers.

Sidek, H. M. (2010c). Reading Instruction: Theory and Practice. Nilai: Usim Publisher.

Sidek, H. M. (2012a). EFL reading instruction: Communicative task-based approach. International Journal of Instruction, 5(2), 109-128.

Sidek, H. M. (2012b). EFL textbook analysis: A case study. Language and Literacy Journal, 14(3), 27-45.

Sidek, H.M. (2012c). Reading Attitudes: A Case Study in Malaysia. Annals of Language and Learning: Proceedings of the 2009 International Online Language Conference (IOLC 2009), p.209. Boca Raton: Universal Publisher

Sidek, H.M. (2012d). EFL Language Learning Personality Traits and Instruction. International Journal of Learning, 18(5), 255-272.

Sidek, H. M. (2013). A Cross-Linguistic Study of Vocabulary Knowledge and Second Language Reading Development. Frontiers of Language and Teaching, 4, 178-185.

Sidek, H. M. (2013). Communicative reading instructional approach: A Curriculum Review. International Journal of Interdisciplinary Educational Studies, 7(1), 9-20.

Sidek, H.M., H. Abdullah, H.A. Rahim \& M. Yuslina. (2014). ESL Reading Instruction: Alignment of Curriculum and Implementation. Procedia-Social and Behavioral Sciences, 118, 442-449.

Sidek, H. M. (2014). English Language Reading Preparation for Higher Education: An Evaluation of the Form Four English Language Textbook and Instructional Design, 22(2), 539-558. Journal of Social Science and Humanities (PERTANIKA).

Sidek, H. M. \& Abdullah, H. (2013). EFL Reading Comprehension and Preparation For Higher Education: A Textbook Analysis. Journal of Teaching and Education, 24(4), 425-435.

Sidek, H. M., Abdullah, H. \& Rahim, H.A. (2013). Reading Curriculum and Instructional Analysis: Preparation for Academic Literacy at Higher Institutions. Journal of Teaching and Education, 2(2), 389-396.

Sidek, H.M., Saad, N.S.M., Baharun, H. \& Idrus, M.M. (2016a). An Analysis of Rhetorical Moves in Abstract in Conference Prioceedings. International E-journal of Advances in Social Sciences, 2(4), 24-31. 
Sidek, H.M., Baharun, H., Saad, N.S.M., \& Idrus, M.M. (2016b). English as a Foreign Language Fluency: A Pilot Study. International E-journal of Advances in Social Sciences, 2(4), 70-79.

Swain, M. (1985) Communicative competence: Some roles of comprehensible input and comprehensible output in its development. In S. Gass \& C. Madden (Eds.), Input in Second Language Acquisition. Rowley, MA: Newbury House.

Swain, M. (1995). Three functions of output in second language learning. In G. Cook \& B. Seidhofer (Eds.), Principles and practice in the study of language. Oxford: Oxford University Press.

Swain, M. (2005). The output hypothesis: Theory and research. In E. Hinkel (Ed.), The handbook of research in second language teaching and learning. Mahwah, NJ: Erlbaum.

Swain, M. \& Lapkin, S. (2002). Talking it through: Two French immersion learners' response to reformulation. International Journal of Educational Research, 37, 285-304.

Vygotsky, L. S. (1978). Mind in Society: The Development of Higher Psychological Processes. Cambridge, MA: Harvard University Press. 